\title{
Hierarchical Challenges in Social Enterprises
}

\author{
Małgorzata MATYJA, Krystian ULBIN \\ Wroclaw University of Economics, Wrocław, Poland \\ \{malgorzata.matyja, krystian.ulbin\}@ue.wroc.pl
}

\begin{abstract}
The authors recognized that there can be certain hierarchical improprieties in some of social enterprises. Precisely, they investigated the organizational situation consisting of the simultaneous overlapping of hierarchical relationships, connecting the superior and subordinate, running in opposite directions. The purpose of the article was to determine the implications of disturbed hierarchical relationships (DHR) in social enterprises. The literature overview revealed that (DHR) could have destructive consequences in an organization. The four following areas which could be negatively affected by the DHR were identified: the overall performance, decision-taking process, conflicts and the quality of superior-subordinate relationships. The results of preliminary empirical research on 23 social enterprises in Poland contradicted these findings. The authors explained this with the accepted methodological limitations on the one hand, but also the possibility of specific leadership and organizational culture in the surveyed enterprises on the other hand.
\end{abstract}

Keywords: Hierarchical Relationships, Chain of Command, Democratic Management, Social Enterprises, Cooperatives, NGO.

\section{$1 \quad$ Introduction}

Social enterprises are a specific form of organizations for which profit in the economic sense is not the only goal. The difference between such an entity and a standard enterprise is that the first one does not seek to maximize profits, nor does it pay dividends to its owners. Of course, social companies run a classical business, but they transfer financial surpluses to achieve the social goal [5]. The purpose of a social enterprise is to implement a specific public benefit point, whereas the business activity is a mean to achieve this purpose.

Social enterprises operate mainly with the intention of professional and social integration of vulnerable or already socially excluded groups. They are created to eliminate the negative effects of unemployment, especially among people with disabilities, women in a difficult life situation, representatives of national minorities, people with low qualifications or after a stay in a prison [13]. They are able to see potential in these employees, which is used in various fields of their activity, selffinancing jobs for these people.

Although social enterprises operate within various organizational and legal forms, most often as a non-governmental organization, a cooperative or even a company, in 
addition to the goal, they are combined by one, overriding value - a human being. Social enterprises see the most valuable capital in people and act for them, often allowing them to participate in both current and strategic management. Such a noble idea sometimes turns out to be difficult to implement, because there is a need to consider many voices, needs and expectations, which are not always the same.

The relatively broad right and the ability of employees to decide about less and more important matters related to the organization complicates the arrangement of hierarchical relationships in organizations. They are often subject to disturbances, which can have both positive and negative effects on various areas of the organization. The purpose of the article is to determine the implications of disturbed hierarchical relationships (DHR) in social enterprises. In particular, the authors intend to examine the organizational situation consisting of the simultaneous overlapping of hierarchical relationships, connecting the superior and subordinate, running in opposite directions.

\section{Data and Research Method}

Conducting the research included the preparation of a survey questionnaire, and then sending it to approximately 400 respondents in electronic form, using traditional mail or during a direct meeting. The survey was addressed to the leaders of social enterprises. The territorial scope of the survey included the Lower Silesia Voivodship in Poland. In the study, the selection of the sample was random and based largely on self-recruitment. The authors are aware that such a method of selection has limited possibilities to deduce from the sample to the entire population. However, it should be remembered that other methods of selecting the units to be tested in this case would probably be even less effective, in particular when it comes to obtaining a satisfactory level of sample implementation. In this context, it should also be mentioned that one of the most important aspects was in this case receiving feedback from as many respondents as possible.

Nevertheless, only 23 respondents filled out the questionnaire, which means that the total rate of responses' return was almost $6 \%$. Their characteristic is presented in table 1. In the sample there were mainly non-governmental organizations and social cooperatives. They are relatively young - established a few and a dozen years ago. They act mainly in education, construction, production, health and beauty, but also in such fields as: gastronomy, consulting, accountant and office services, cleaning or recreation and tourism. Their serve mostly local and regional market, but some of them have also national or international scope. They are relatively small in terms of number of employees. They employ workers/members in a difficult situation mainly due to disability, old age and lack of education.

The survey was preliminary research, in which respondents were asked about their opinion. Therefore, the obtained data is subjective. The aim of the empirical research was just to find out whether the disturbed hierarchical relationships occurred in analyzed organizations and whether they negatively influenced the overall performance, decision-taking process, conflicts and the quality of superior-subordinate relationships. 
Table 1. Basic characteristics of the research sample.

\begin{tabular}{|c|c|c|c|c|c|c|c|c|c|}
\hline \multicolumn{2}{|c|}{ Legal form } & \multicolumn{2}{|l|}{ Established } & \multicolumn{2}{|l|}{ Industry } & \multicolumn{2}{|l|}{ Scope } & \multicolumn{2}{|c|}{$\begin{array}{l}\text { Number of } \\
\text { employees }\end{array}$} \\
\hline NGO & 13 & $1990-2003$ & 2 & Education & 7 & Local & 8 & Up to 5 & 8 \\
\hline Social coop. & 9 & 2004-2013 & 15 & Construction & 4 & Regional & 5 & 6-10 & 2 \\
\hline \multirow[t]{3}{*}{ Other } & 1 & 2014/later & 6 & Production & 3 & National & 6 & $11-20$ & 7 \\
\hline & & & & Health/beauty & 3 & Internation. & 4 & $21-50$ & 5 \\
\hline & & & & Other & 14 & & & $51-250$ & 1 \\
\hline
\end{tabular}

\section{$3 \quad$ A literature Overview}

In a workplace unique interpersonal relationships with important implications for the individuals and the organizations exist and develop [6]. Among different workplace relationships one of the most important are the relationships between superior and subordinate $[1,6,12]$. A typical example of such relationship is the hierarchical relationship which results from the division of authority (the power to make decisions) [10]. It is often replaced by the term "chain of command", "scalar chain" or "line of authority". According to its original proponent H. Fayol and his scalar principle, from the lowest to the highest position in an organization a clear and uninterrupted line of authority should be observed [4, 7]. In other words, hierarchical relationships should be directed from top to bottom - from supervisor to subordinate [11].

Additionally, the deep subject considerations of the representatives of praxeological trend in the theory of organization and management have led to the conclusion that hierarchical relationship, described as "official relationship", is always, bearing in mind one case, one-sided [17]. However, this does not eliminate the possibility of occurrence of official relationship between the same team members inversely directed bearing in mind another case. Moreover, this allows a change of direction of the relationship between the same members in another case of the same type [18]. Thus, theoretically there may exist a situation in which two workers, even supervisor and his subordinate, simultaneously are connected by hierarchical relationships running in opposite directions.

Although the analyzed problem seems to be entirely theoretical - what would happen if the subordinate had a bigger power than his supervisor? - it is reflected in the practice of some organizations, including especially social enterprises. It could occur for example in social cooperatives, whose members have the ownership and are at the same time employed. Out of all the members, belonging to the general assembly, the supervisory board monitoring the activity of the whole cooperative and management board, is selected. The managerial positions in a cooperative, including also the boards, can be taken by employees from outside the members, who bearing in mind their position supervise other members - also those who belong to the supervisory board. In such way, the tangle of hierarchical relationships is formed.

The disturbances in chain of command could have some consequences in an organizations. According to Fayol, "the clearer the division of hierarchical relationships 
is, the more effective the process of decision taking, and effectiveness become" [quote for 4]. Hart and Moore [8] recognized that "crisscross" hierarchies were never optimal. Also, J. C. South and K. Matejka [15] drew the attention to the existence of the socalled multiple weak links in the chain of hierarchical relations and their influence on the general results of an organization. Therefore, it can be claimed that the disturbed hierarchical relationships do not favour the overall organization performance.

Syriopoulos and Tsatsaronis [16] convinced that the unification and integration of the command chain implies a faster decision-taking process. Oginni et al. [12] and Sanner and Bunderson [14] emphasized that it helped to avoid confusion, conflicts and stalemates. The research by J. W. Kassing [9] indicated the existence of both constructive and destructive consequences of circumvent by employees the chain of hierarchy in the context of supervisor-subordinate relations. As pointed out by Abu Bakar and Mustaffa [1], the superior-subordinate communication behaviour plays an important role in affecting the quality of the relationship between superior-subordinate and group commitment.

From the various studies adduced so far, we can identify a following organization fields which could be affected by the disturbed hierarchical relationships: the overall performance, decision-taking process, conflicts and the quality of superior-subordinate relationships. This study verifies whether this really happens in the practice of some organizations.

\section{$4 \quad$ Research Results}

Because social enterprises often enable their workers or members to participate in managing the selected fields or even the entire organization, the respondents were firstly asked to answer the question about the occurrence of such democratization. The results confirmed the above assumption (Fig. 1). Nearly $80 \%$ is familiar with the

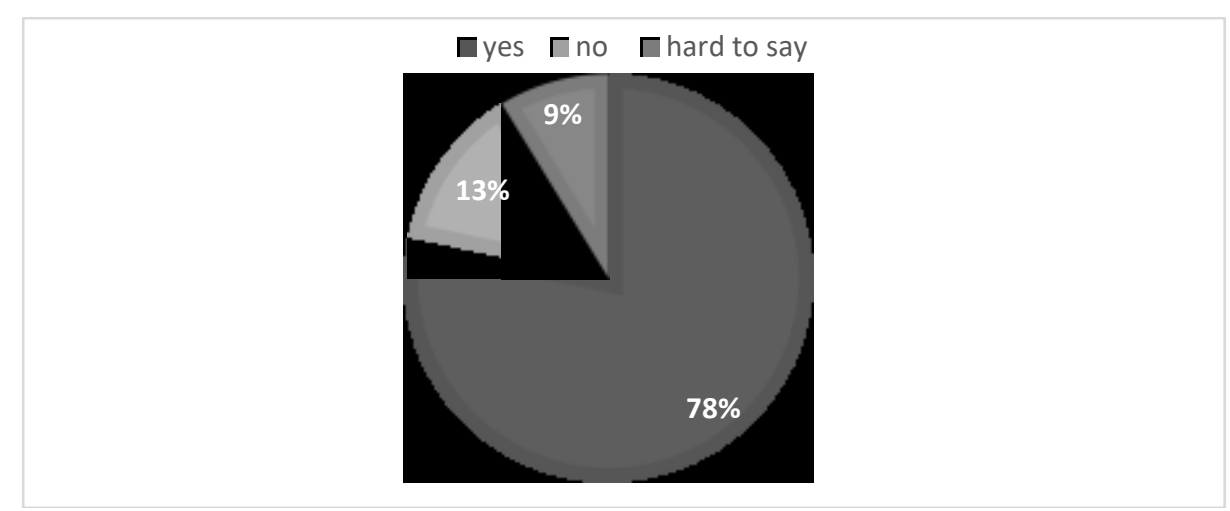

Fig. 1. The occurrence of democratic management.

phenomenon of democratization of management, while 13\% declared no existence of democratic procedures in managing their organization. 
Next, the respondents presented their opinion on the impact of democratization on the current management in the organization (Fig. 2). It turns out that over half of them (twelve answers) claims that democratic procedures support the management and only three deny this statement. Similarly, ten respondents said that, contrary to popular opinion, the democratization did not hinder the management and governance.

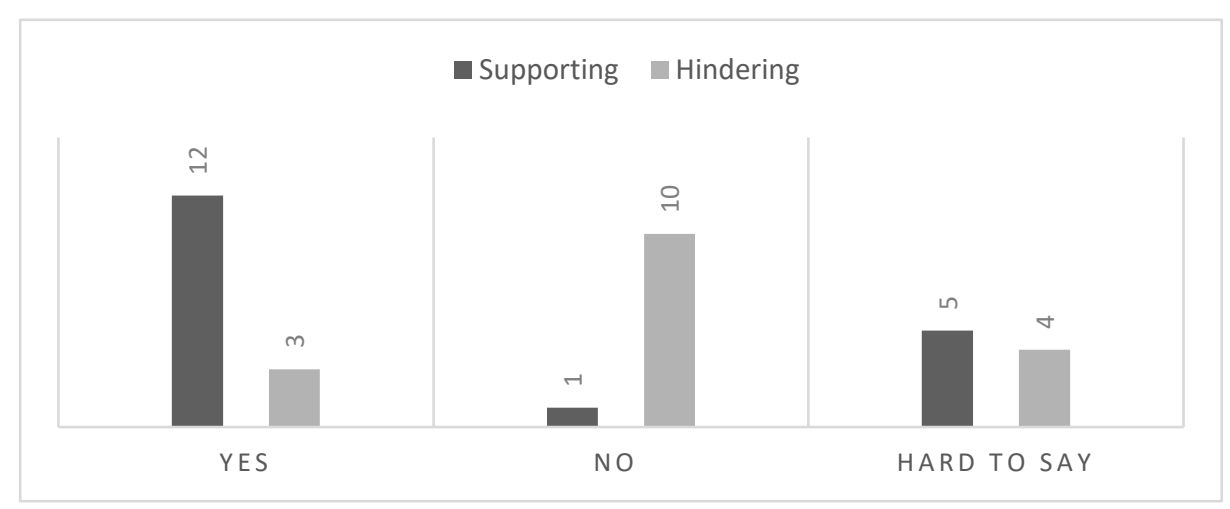

Fig. 2. The character of the impact of democratization on the current management.

Further, the respondents evaluated the presence of disturbed hierarchical relationships in their organizations (Fig. 3). Precisely, they were asked to answer the following question: "Does a phenomenon in which a board member is at the same time the subordinate of a given manager occur in your organization?" The authors are aware, that such disturbance in hierarchical relationships is only one in many possible.

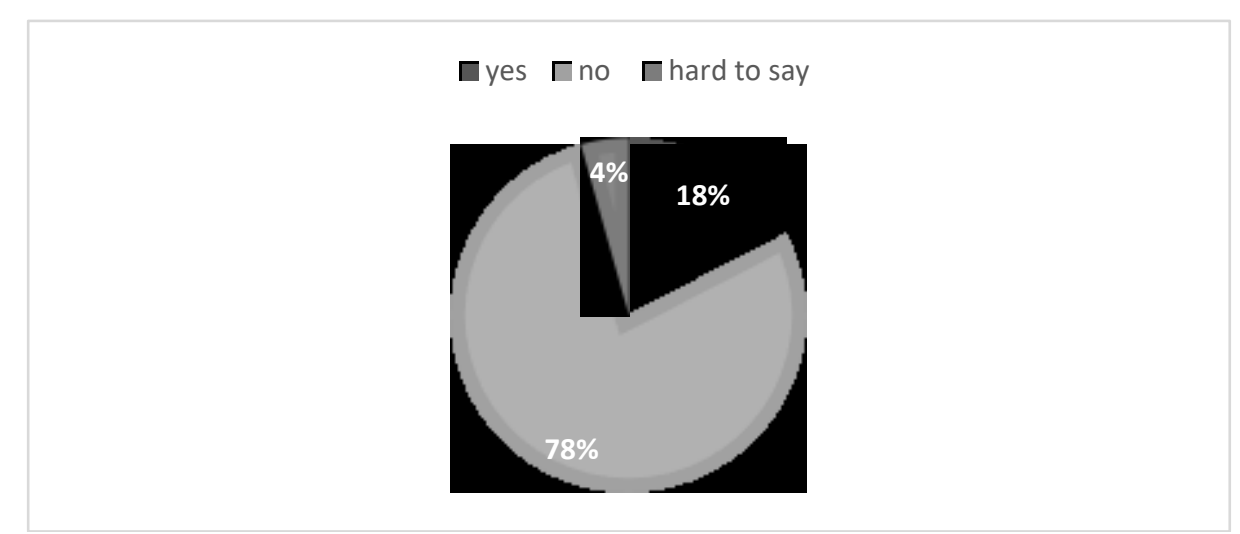

Fig. 3. The occurrence of disturbed hierarchical relationships.

However, they simultaneously considered it the most common and easy to understand. The results indicate that, unlike the phenomenon of democratization of 
management, DHR are not as frequent. Only $18 \%$ confirmed their existence. $78 \%$ definitely denied their occurrence.

Finally, the respondents determined the implication of DHR on different fields of their organizations. Precisely, the questions were as follows: "Do you think the DHR affects negatively the overall performance/decision-taking process/the quality of superior-subordinate relationships" and "Do you think DHR causes conflicts in your organization?" The aggregate results in this area are presented in Fig. 4.

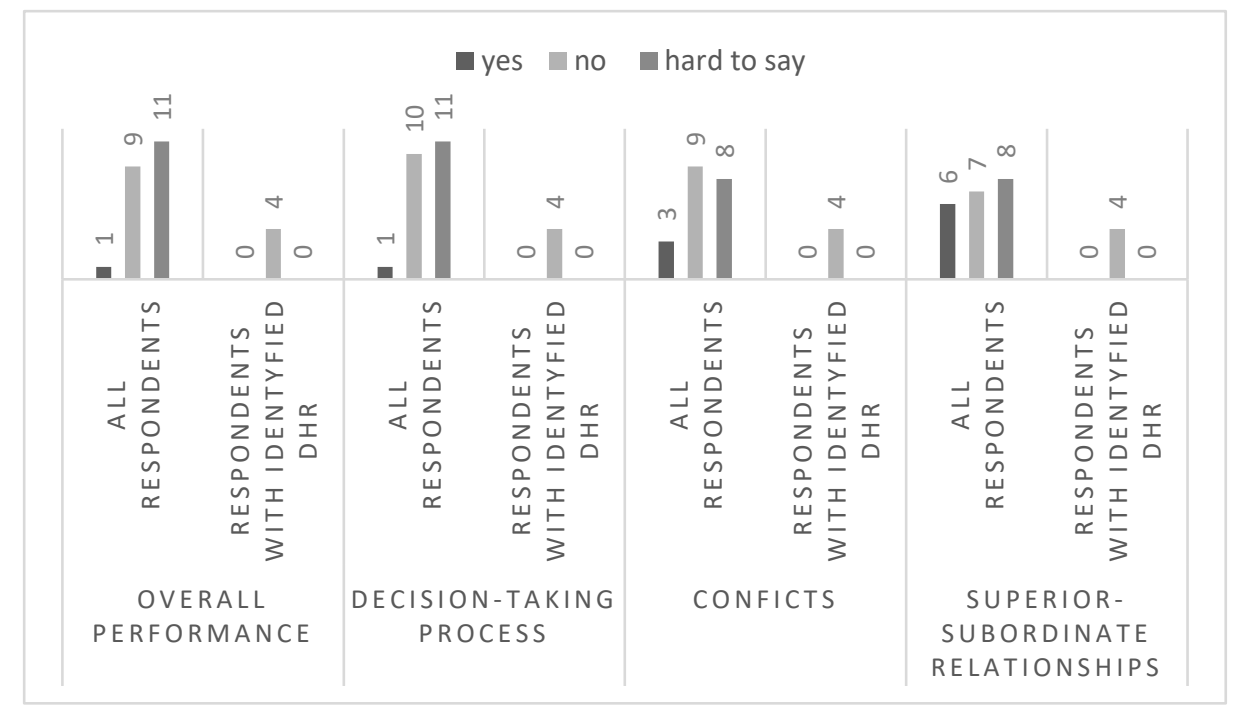

Fig. 4. The number of answers to the questions about the negative impact of DHR on different fields in an organization.

Taking into account the answers of all respondents, it can be observed that they either had problems with determining the implications of DHR or denied their negative impact. In particular, this applies to areas such as: the overall performance and the decision-taking process. In these cases this was stated by all respondents with one exception. There were, however, three responses in the case of conflicts and six in the case of a supervisor-subordinate relationship suggesting that DHR negatively affect these fields.

However, the most valuable were the comments of these respondents, although few, but who found the existence of DHR. It turned out that they all denied the negative impact of DHR on all analyzed areas. Thus, they definitely undermine the significance and consequences of disturbances in hierarchical relationships.

\section{Discussion}

The conducted survey revealed the unexpected findings. Unexpected, because they provide no support for the results of the above reviewed researches. The opinion of 
peoples who work in unclear chain of command conditions, showed no correlation between the occurrence of DHR and the general effectiveness of an organization and the speed of decision making. This contradicts the findings of Fayol, Hart and Moore, South and Matejka, as well as Syriopoulos and Tsatsaronis $[4,8,15,16]$. There is also no explicit confirmation, that disturbances in hierarchical relationships causes more conflicts and confusion, as it was in Oginni's et al. [12] and Sanner's and Bundersons's [14] works. On the basis of the research results this paper argues also the negative impact of DHR on superior-subordinate relationships, which denies the findings of Abu Bakar and Mustafa [1] and only partially agrees with Kassing [9].

However, the authors suggest caution in interpreting the obtained results due to the limitations of the research sample and the adopted research methodology. Firstly, the sample was very small, what definitely does not allow to inference about the entire population. And secondly, the collection of information included only the opinion of the respondents and not objective, hard data based on operationalized terms and concepts. The latter seems to be more reasonable and reliable. Some of the respondents presented their opinion on issues that do not concern them, which additionally gives a certain view, but also inclines to think about the reliability of the results.

On the other hand, the findings of this paper, despite being limited in interpretation, can be also considered as valuable because they provoke to think deeper about the disturbances of hierarchical relationships in social enterprises. Therefore, the authors pose questions indicating further directions and areas of research.

First of all, since the findings have shown that there is no destructive influence of DHR, are there any indications that this influence could be considered as constructive [9]? Do they support management procedures in social enterprises? In this context the authors suggest searching for also the positive implications of DHR in different fields in organizations.

Moreover, since the findings contradict the current literature conclusions on the negative impact of DHR, it should be determined why it is so. The authors advocate two possible ways of explanation for this phenomenon. First suggest to investigate the role of the leadership, managerial competences and the division of authority. For example Aghion and Tirole [2] prove that there is a difference between "formal authority" related to power, control and "real authority" combined with leadership, the ability to influence subordinates. The elimination of negative consequences of DHR may be connected with using the "real authority" by the superior over his subordinate. Such practices may help to avoid potential conflicts and control the tangle of hierarchical relationships.

The second explanation refers to very essence and specificity of social enterprises. They are entrepreneurial organizations that do not have as their main objective the maximization of private returns (net surpluses or profits), but the protection of their members through the satisfaction of their needs [3]. Hence, the workers/members' awareness of this purpose could be stronger that than the desire to use and show the position in the hierarchical structure. It should also be noted that social enterprises are relatively small and young and associate often peoples with social problems (e.g. social cooperatives). Therefore the values like entrepreneurship, dynamic development and 
willingness to act also for the common good could overcome the importance of internal conditions of the organizational structure and the possibility of using the formal power.

\section{Conclusion}

Hierarchy exists in every organization. Thus, the chain of command has a great importance. However, in employee-managed firms it often gains complexity by entanglement of hierarchical relationships resulting from enabling employees to participate in management. The situation of simultaneous overlapping of hierarchical relationships between supervisor and subordinate passing in opposite directions induces dualism of the chain of command. This, in turn, could have negative consequences for different fields in an organization.

However, as shown above, in social enterprises it has special features and it manifests in a specific way. This paper developed an approach of considering hierarchical problems in social enterprises. Precisely, it investigated the situation consisting of the simultaneous overlapping of hierarchical relationships, connecting the superior and subordinate, running in opposite directions. On the basis of the literature overview it revealed that such disturbed hierarchical relationships (DHR) could have destructive consequences in an organization. The four following areas which could be negatively affected by the DHR were identified: the overall performance, decisiontaking process, conflicts and the quality of superior-subordinate relationships. However, the results of preliminary empirical research conducted on 23 social enterprises in Poland contradicted these findings. The authors explained this with the accepted methodological limitations on the one hand, but also the possibility of specific leadership and organizational culture in the surveyed enterprises on the other hand.

Nevertheless, taking into account the discussed and concluding remarks it seems to be justified to conduct more sophisticated research on hierarchical problems in social enterprises. Eventually, the conducted research gives a certain important view on the analyzed issues, and its contribution can be used for a broader analysis of the functioning of social companies.

\section{References}

1. Abu Bakar, H., Mustaffa, C. S.: Relationships Quality and Group Commitment. Malaysian Journal of Communication 24, 20-33 (2008).

2. Aghion, P., Tirole, J.: Formal and Real Authority in Organizations. Journal of Political Economy 105(1), 1-29 (1997).

3. Borzaga, C., Depedri, S., Tortia, E.: The Role of Cooperative and Social Enterprises: a Multifaceted Approach for an Economic Pluralism. Euricse Working Papers 09, 1-20 (2009).

4. Crumption M.: Is the chain of command working for you? The Bottom Line: Managing Library Finances 26(3), 88-91 (2013).

5. Defourny, J.: Przedsiębiorstwo społeczne w poszerzonej Europie: koncepcja i rzeczywistość. In: Ekonomia społeczna: II Europejska Konferencja Ekonomii Społecznej, Kraków 2004, pp. 43-65. Ministerstwo Polityki Społecznej, Warszawa (2005). 
6. Gaur, M., Ebrahimi, N.: Understanding Workplace Relationships - With Special Reference to Superior-Subordinate Relationship - An Important Dimension Having Impact On The Success, Growth And Performance of the Employees And Organization. International Journal on Research and Development - A Management Review 2(2), 7-12 (2013).

7. Griffin, R. W.: Podstawy zarządzania organizacjami. Wydawnictwo Naukowe PWN, Warszawa (2004).

8. Hart, O., Moore, J.: On the Design of Hierarchies: Coordination versus Specialization. Journal of Political Economy 113(4), 675-702 (2005).

9. Kassing, J. W.: Breaking the chain of command: Making sense of employee circumvention. Journal of Business Communication 46(3), 311-334 (2009).

10. Kozina, A.: Pojęcie i rodzaje zależności organizacyjnych. Zeszyty Naukowe Akademii Ekonomicznej w Krakowie (323), 21-37 (1990).

11. Morgan, G.: Obrazy organizacji. Wydawnictwo Naukowe PWN, Warszawa (1997).

12. Oginni, B. O., Gbadegesin, A., Patience, E.: A Study of Superior-Subordinate Relationship and Employees' Commitment to the Core Beliefs of Organisation in Public Universities of Southwest, Nigeria. American Journal of Business and Management 3(1), 28-38 (2014).

13. Pacut, A.: Przedsiębiorczość społeczna w Polsce - problemy i wyzwania. Zarządzanie Publiczne 4(14), 45-58 (2010).

14. Sanner, B., Bunderson, J. S.: The Truth About Hierarchy. Mit Sloan Management Review 59(2), 49-52 (2018).

15. South, J.C., Matejka, K.: Unmasking multiple weak links in the chain of command. Management Decision 28(3), 22-26 (1990).

16. Syriopoulos, T., Tsatsaronis, M.: Corporate Governance Mechanisms and Financial Performance: CEO Duality in Shipping Firms. Eurasian Business Review 2(1), 1-30 (2012).

17. Zieleniewski, J.: Organizacja zespołów ludzkich: wstęp do teorii organizacji i kierowania. Wydawnictwo Naukowe PWN, Warszawa (1972).

Zieleniewski, J.: Organizacja i zarządzanie. Wydawnictwo Naukowe PWN, Warszawa (1981). 